program will produce useful electronic catalogues of the provincial flora, because the SASK collection remains a fundamental, rich source of historical, ecological, geographical, morphological, and taxonomic data. SASK databases will greatly facilitate the extraction of such data for use in a wide diversity of taxonomic and conservation-oriented research at the provincial and national levels.
1. COTA-SÁNCHEZ, J.H., R. OLSON, and J. HARALDSON. 2004. The type collection of the W. P. Fraser Herbarium. Polibotánica 17:131-138.

2. HARMS, V.L. 2003. Checklist of the Vascular Plants of Saskatchewan and the Provincially and Nationally Rare Native Plants of Saskatchewan. University Extension Press, University of Saskatchewan, Saskatoon, SK.

3. HOLMGREN, P. K., and N. H. HOLMGREN. 1998. Index Herbariorum: A global directory of public herbaria and associated staff. New York Botanical Garden's Virtual Herbarium. http:/l sweetgum.nybg.org/ih/

\title{
THE GEORGE F. LEDINGHAM HERBARIUM, UNIVERSITY OF REGINA
}

\author{
ELIZABETH BARKER, LB 152, University of Regina, 3737 Wascana Parkway, \\ Regina, SK, S4S 0A2; E-mail: <barker1e@uregina.ca>
}

The George $F$. Ledingham Herbarium was founded in 1945 by Dr. George Ledingham and was named after him in 1990. George remained an active curator of the Herbarium until well into his 90 s and, when he became unable to tend the Herbarium daily, continued to visit occasionally.

The Herbarium houses approximately 50,000 vascular plant specimens, 10,000 bryophytes, and 10,000 mosses, collected from 1901 to the present. A special Grasslands National Park collection, comprising a few hundred specimens, was set up by George, to whom the Park project was near and dear. A new (2008) addition to the Herbarium is a number of plants collected at White Butte by Inga Hiiesalu, a Master's student supervised by Dr. Scott Wilson of the University of Regina.

One Herbarium cabinet is filled with Astragalus, a genus on which George did a great deal of research. This genus, which belongs to the family Fabaceae, includes numerous species of milkvetch, locoweed, and goat's-thorn. A particularly interesting specimen is Astragalus ledinghamii, collected by George in Iran in 1965 and named after him by R. C. Barneby (Fig. 1). George noted that in the area where he collected $A$. ledinghamii, the land was potentially fertile but barren from overgrazing. "Now the goats (millions), sheep, donkeys [and] camels travel about eating every blade of grass as soon as it comes out of the ground. The grass never matures seed and soon disappears," he wrote. One Iranian told George that he had come 20 years too late because the large, thorny species of Astragalus in the locale were being used for firewood.

During the winter of 2006, George attended a coffee social held by the Department of Biology. A few years earlier, as an undergraduate student taking a course in plant taxonomy, I had studied specimens in the Herbarium, profiting from George's expertise and enjoying his friendliness and his enthusiasm for plants. I was happy to see him again and sat down to chat with him. I don't think George knew who I was, but he was determined to 


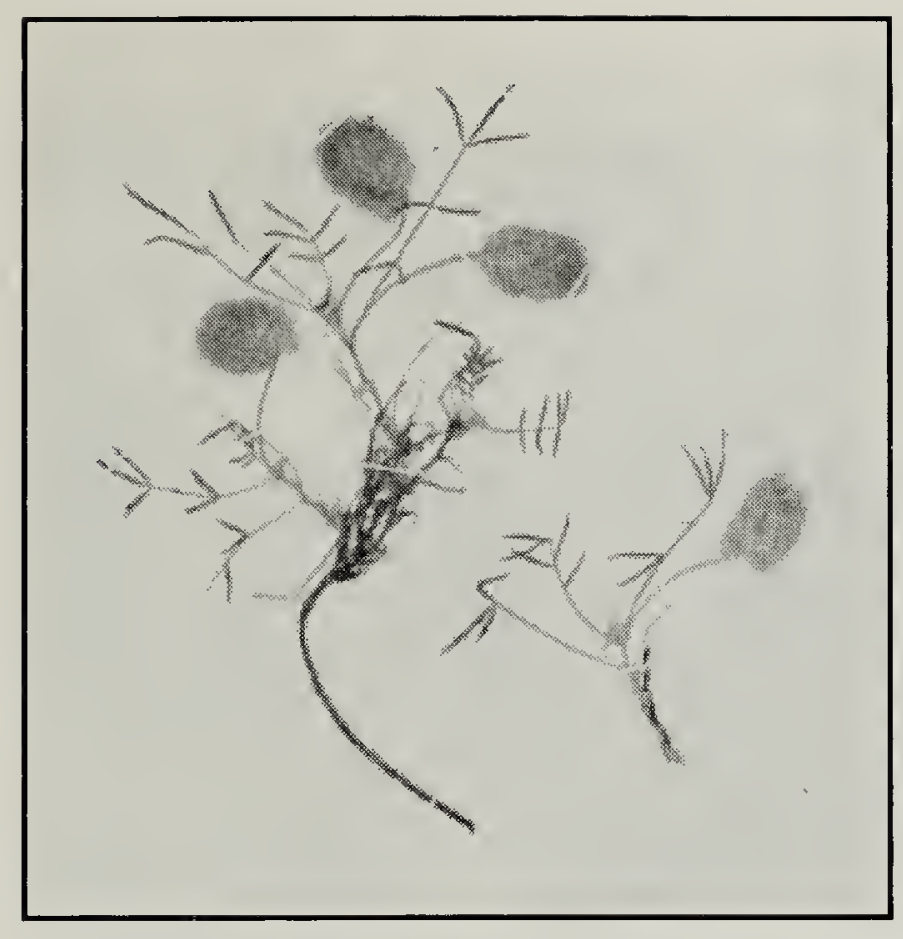

Figure 1. Herbarium specimen of Astragalus ledinghamii, collected by George Ledingham in Iran.

Don Hall, University of Regina.

express his concern for the Herbarium to anyone who would listen. I promised him that I would see that the Herbarium was looked after. Sadly, George passed away in October of that year*, shortly after making a last trip to the Herbarium for a photo session with Don Hall, who was preparing an article that appeared in the University of Regina's Degrees magazine later that month.

During the last 3 years, with assistance as needed from Dr. Mary Vetter, I have responded to requests for plant identification and information about plant mutations from members of the general public, provided information about locations of rare specimens to conservationists, and processed loans of specimens to researchers. Visitors to the Herbarium have studied Saskatchewan plants, particularly rare species, to aid in their field work.

Increasing petroleum and natural gas (PNG) activity in the southern part of our province has a profound impact on prairie plants. Some of the conservationists who are responsible for ensuring that land disturbed by PNG activity is restored as nearly as possible to its pre-disturbance condition have expressed the concern that they are able to identify only the common plants. Working with herbarium specimens is an indispensable aid to identification, and we encourage workers to visit the George F. Ledingham Herbarium to familiarize themselves with rare species. We feel that this is an important role for the Herbarium to play in conserving Saskatchewan vegetation and welcome any opportunity to open the Herbarium for use.

We are interested in building a database of Herbarium specimens using Specify software, which is designed for that use. One of the George F. Ledingham Herbarium volunteers has attended a Specify workshop given at the W.P. Fraser Herbarium, University of Saskatchewan, and we have conferred with the Fraser Herbarium about coordinating our efforts with theirs. If any of the Blue Jay's readers would be interested in volunteering to participate in this effort, we would appreciate it. There is a small corps of volunteers who are anxious to get started on this project.

Please plan to visit the George F. Ledingham Herbarium soon. I will be delighted to orient you to the Herbarium and assist you in locating specimens if you wish. I can be contacted using the information provided above.

"EDITORS' NOTE: For more information on George Ledingham's life, please see the In Memoriam entitled "George F. Ledingham (19112006)" by C. Stuart Houston and Robert W. Nero, Blue Jay 64(4): 225227. 